\title{
Confirmation of Aloysia dusenii Moldenke (Verbenaceae) for South Brazil: implications for conservation
}

\author{
Matias Köhler 1,2,3* \\ Cassio Rabuske da Silva ${ }^{2,3}$ \\ Paulo Brack ${ }^{2,3}$ \\ 'Programa de Pós-Graduação em Botânica, Universidade Federal do Rio Grande do Sul \\ Campus do Vale, CEP 91501-970, Porto Alegre - RS, Brasil \\ ${ }^{2}$ Instituto de Biociências, Departamento de Botânica, Universidade Federal do Rio Grande do Sul, Campus do Vale, \\ CEP 91501-970, Porto Alegre - RS, Brasil \\ ${ }^{3}$ Instituto Gaúcho de Estudos Ambientais, CEP 90010-320, Porto Alegre - RS, Brasil \\ * Autor para correspondência \\ matias.k@ufrgs.br
}

Submetido em 29/11/2017

Aceito para publicação em 12/03/2018

\section{Resumo}

Confirmação de Aloysia dusenii Moldenke (Verbenaceae) para o sul do Brasil: implicações para a conservação. Aloysia dusenii Moldenke (Verbenaceae) é uma espécie reófita endêmica da região Sul do Brasil. Habita beira de rios, sobre afloramentos rochosos com cursos d'água rápidos. Recentes revisões, tratamentos taxonômicos e coletas em campo confirmaram a ocorrência desta espécie para a região sul do Brasil. Com os dados atuais de distribuição, é apresentado o status de conservação desta espécie, de acordo com os critérios da IUCN. As primeiras fotos de A. dusenii em campo são fornecidas para a literatura. É destacada a importância da inclusão desta espécie nas listas regionais de flora ameaçada de extinção, tendo em vista sua restrita área de ocupação e o alto grau de ameaça que seu ambiente tem sofrido por barragens e empreendimentos hidrelétricos.

Palavras-chave: Espécies ameaçadas; GeoCat; Hidrelétricas; Reófitas

\section{Abstract}

Aloysia dusenii Moldenke (Verbenaceae) is a rheophyte species endemic to South Brazil. The species inhabits riverbanks on rocky outcrops along rivers with swift-running streams. Recent revisions, taxonomic treatments and field work have confirmed the species for South Brazil. In this note, the distribution records of $A$. dusenii were compiled and a proposal was made to classify the conservation status of this species according to IUCN guidelines. The first photographs of $A$. dusenii in field were provide for the literature. The importance of including this taxon in the regional lists of endangered flora is emphasized in view of the great threat to their environment coming from dams to hydroelectric projects.

Key words: Endangered species; GeoCat; Hydroelectric dams; Rheophytes 


\section{Introduction}

Aloysia Paláu is an endemic genus of the New World, mainly found in subtropical regions and in the Andes (O'LEARY et al., 2016). The genus has a blurred taxonomic history with different circumscriptions according to authors and analyzed characters (BENTHAM; HOOKER, 1876; MOLDENKE, 1959; MARX et al., 2010; LU-IRVING; OLMSTEAD, 2013; LU-IRVING et al., 2014).

Recent molecular phylogenetic studies have made new combinations and arrangements to be able to establish a well-supported monophyletic Aloysia (LU-IRVING et al., 2014). Therefore, this new circumscription comprises 31 species, whose members are shrubs and small trees with dry fruits and long racemose florescences with the rachis longer than the peduncle, and alternate or opposite flowers (O'LEARY et al., 2016). The genus, as newly circumscribed, is almost exclusively found in South America, with only three species restricted to North America.

Aloysia dusenii Moldenke was described in 1940 based on material collected from Per Karl Dusén at Paraná State (Brazil) in 1914 (MOLDENKE, 1940; Type: P.Dusén 1050a at NY, S), and so far, few records have been checked for the region. The collections of Gerdt Hatschbach made in the $20^{\text {th }}$ century in Southern Brazil deserve attention. Hatschbach was one of the largest plant collectors in the last century with more than 80,000 specimens, especially in Paraná State, and all Aloysia materials from Hatschbach were studied by Moldenke. However, the formal inclusion of $A$. dusenii in the Brazilian flora was done only recently (BFG, 2015; O’LEARY et al., 2016).

Siedo (2006), in his dissertation regarding the systematics of Aloysia, cited the species for the states of Paraná, Santa Catarina and Rio Gande do Sul. Despite that, Múlgura et al. (2008) mentioned A. dusenni only for Paraná, and Crespam (2010) did not confirm the species for Rio Grande do Sul. Moreover, Salimena et al. (2010) mentioned the species as belonging to thefor Brazilian flora of Rio Grande do Sul, Paraná and Santa Catarina, but citing material only for Paraná.
A recent taxonomic revision of Aloysia provided comprehensive and reliable information about the identity and circumscription of the species of the genus (O'LEARY et al., 2016). However, the authors did not seem to know about populations of $A$. dusenii in the field, where they did not mention any data regarding the conservation status of the species. Based on field work and revision of regional herbarium collections, we determined the distribution of the species and provide a proposal to classify the conservation status of this species according to IUCN guidelines.

\section{Materials and Methods}

The distribution records of Aloysia dusenii were compiled using online database of collections available on SpeciesLink (http://www.splink.org.br) and Reflora - Virtual Herbarium (http://reflora.jbrj.gov.br/reflora/ herbarioVirtual/), considering the synonyms according to O'Leary et al. (2016). We also compiled data contained in the taxonomic literature and biodiversity inventories. All data were checked for accuracy and validity of the geographic coordinates through data cross-checking with databases of political units of Brazil in GIS (Google Earth $^{\circledR}$ ) and label data. Additionally, we confirmed the identity of the species deposited in the ICN and MBM herbarium (acronym according to Thiers, 2017), the collections with most representative materials, and all the images online available from others herbaria.

The IUCN conservation status of $A$. dusenii was assessed using the criteria of the IUCN Red List (IUCN, 2012). The extent of occurrence (EOO) and the area of occupancy (AOO) were calculated with GeoCAT (BACHMAN et al., 2011; BACHMAN; MOAT, 2012), using cell width of $4 \mathrm{~km}$ based on our observations. Field and label data were also used to enhance the categorization.

\section{Results and Discussion}

Aloysia dusenii Moldenke is an endemic species of South Brazil and has been observed to grow strictly on riverbanks and rocky outcrops along rivers (Figure 1A-C). This characteristic was corroborated by all 
the label data that we analyzed, which reported plants growing on riverbanks or in marginal riparian forests. Rheohphyte is a term coined by Van Steenis $(1981 ; 1987)$ to refer to plants that grow along the margins of swift water currents or on the streambed and its rocks, adapted to withstand the force of water with particular traits in their architecture, roots, leaves, flowers and fruits, which facilitate their resistance to the strong currents. A species may be exclusively, preferably or occasionally rheophyte, and A. dusenii seems to be exclusive to this environment.
Aloysia dusenii is notable in relation to its bilobulated calyx (Figure 1B), which is 4-toothed in the rest of the South American Aloysia taxa. Two records found at ICN were mistakenly identified as $A$. dusenii, and we proved that the correct identification was $A$. gratissima (Gillies \& Hook. ex Hook.) by its 4-toothed calyx and additional leaf characters. Additionally, these two records were from habitats very distinct from those where $A$. dusenii occurs, being an additional characteristic of the species.

FIGURE 1: A. Aloysia dusenii, as sub-shrub, in its natural habitat. B. Detail of a floriferous branch of A. dusenii with bilobulated calyx (see zoom in red arrow). C. General aspects of rheophytic habitat with rocky outcrops and swift-running streams.
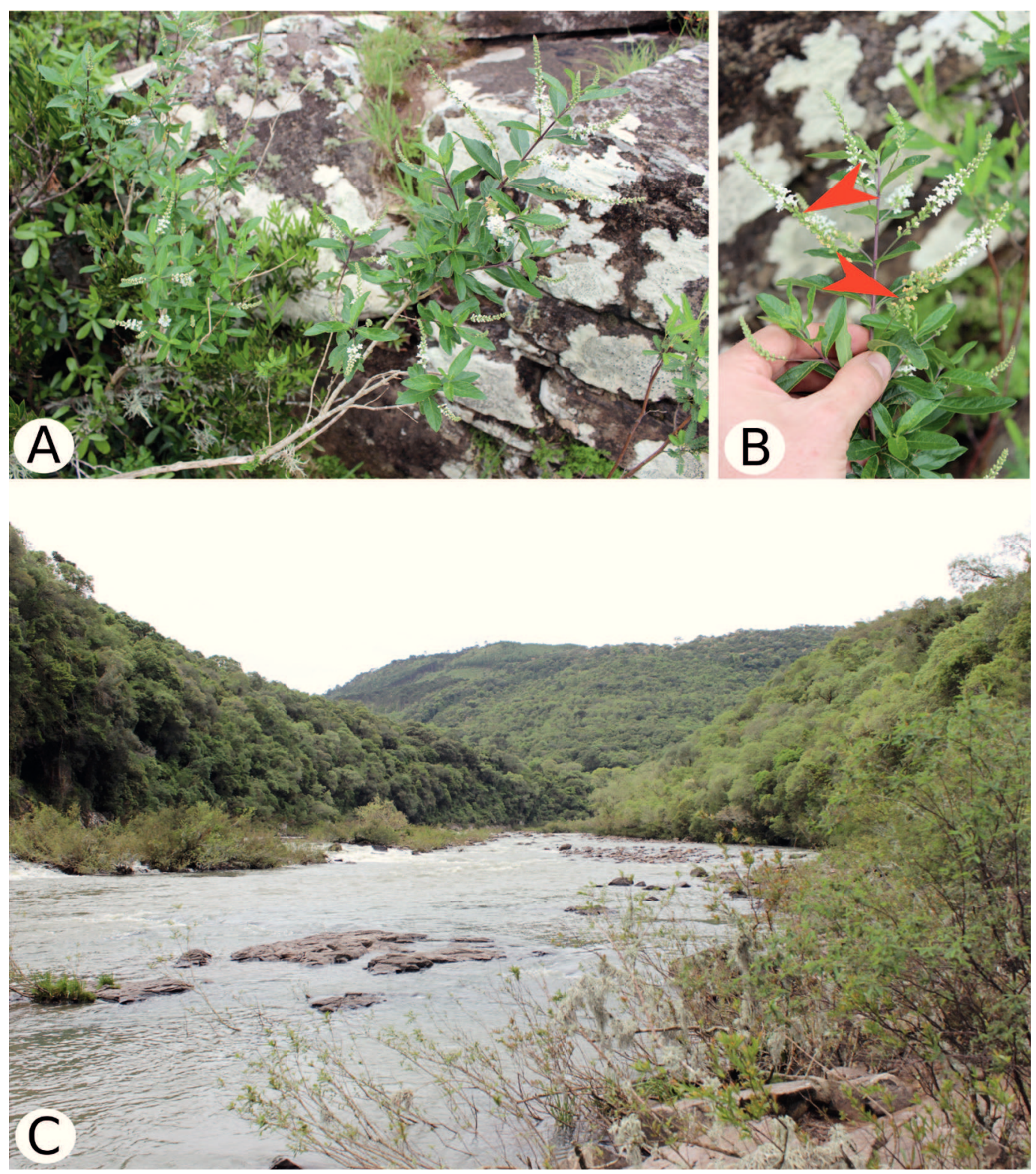
We confirmed 25 records of $A$. dusenii in South Brazil: 17 (68 \%) in Paraná, 5 (20\%) in Santa Catarina and $3(12 \%)$ in Rio Grande do Sul (Figure 2A, see in Supplementary Materials the Specimens Examined). No material was found for the State of Pará, Brazil, although the species is currently cited for this region (MORRONI; O'LEARY, 2017). This is probably related to some orthographic or phonetic error, given the similarity between "Paraná" and "Pará" spellings, because Aloysia is reported only as being cultivated in Pará State.

The predominance of collections for Paraná may be related to the sample effort expended by Hatschbach in that region. However, we know that Santa Catarina was also relatively well studied by the "Flora Ilustrada Catarinense", planned by Raulino Reitz, but there is no material of $A$. dusenii coming from these efforts. Thus,

FIGURE 2: A. Distribution records of Aloysia dusenii in South Brazil (dashed lines are rivers associated with occurrences; white circles represent areas of occurrence). B. Impacts of a river dam: transformation of lotic environment into lentic habitat, and death of many species.

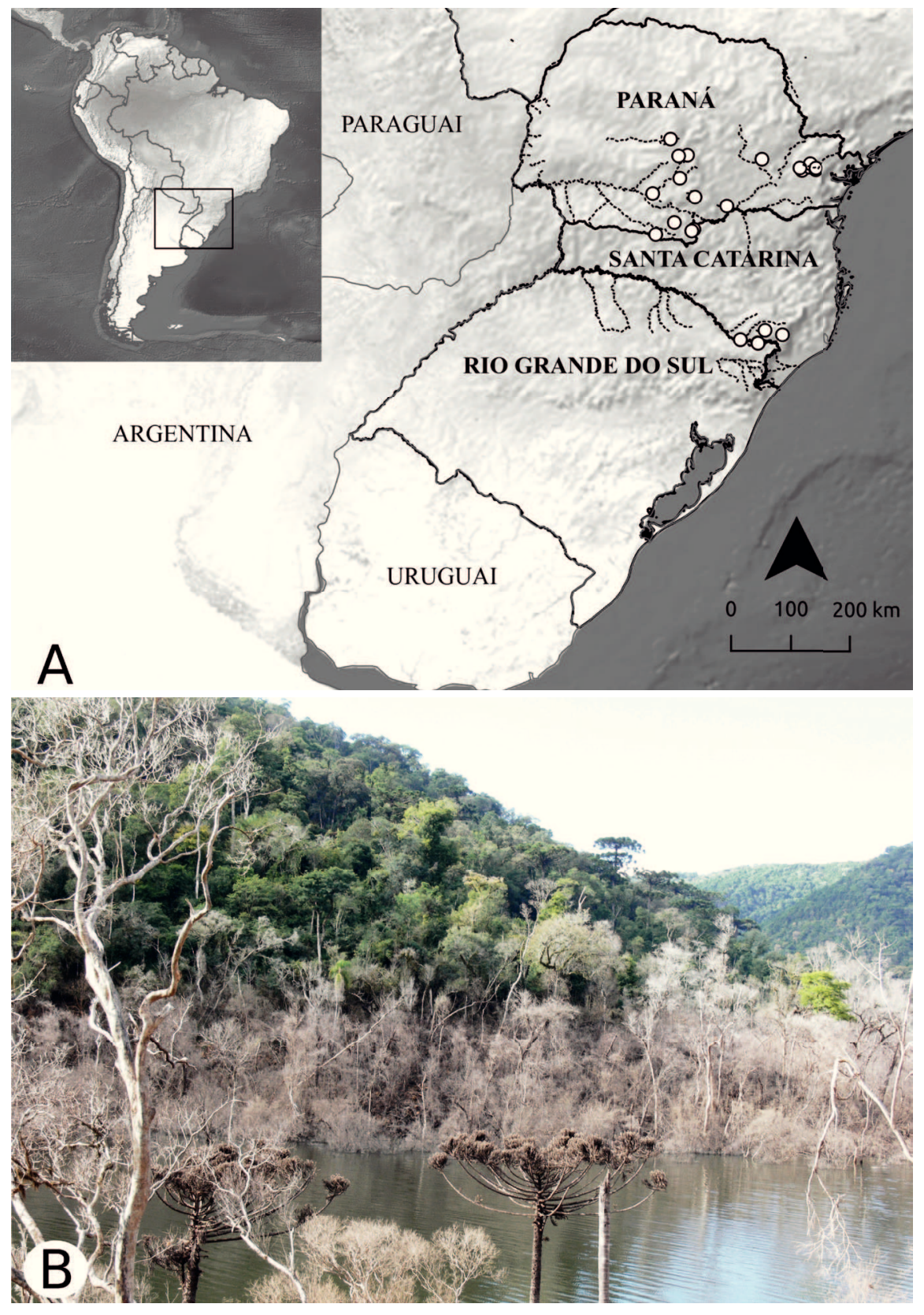


we still do not know if the largest number of records in Paraná is due to the species being more frequent in that region than in the others or if there are gaps to be filled.

\section{Proposed IUCN Conservation Assessment}

This species is given an IUCN Red List Category of Endangered: EN B2b(ii,iii)c(ii,iii). The extent of occurrence (EOO) of the species is estimated to be $84,972.978 \mathrm{~km}^{2}$, whereas its area of occupancy (AOO) is estimated to be $352 \mathrm{~km}^{2}$, which falls within the limits for EN status under the subcriterion B2. Also considering factors such as continued decline projected for the area of occupancy (b[ii]), decrease in habitat quality (b[iii]); extreme fluctuations in the area of occupancy (c[ii]) and in the number of locations or subpopulations (c[iii]), the species qualifies under conditions " $b$ " and "c" of Endangered (IUCN, 2012).

Rheophytes are usually poorly studied, probably due to the difficulties in accessing their habitat. Few studies are reported for South America with a community or floristic approach (KLEIN, 1979; FONTANA, 2001; BERNARDES, 2012; KÖHLER et al., 2016; HOYOS-GÓMEZ; BERNAL, 2018). Most records of rheophytic species are from individual plants, sometimes new to scientific community (GALEANO-GARCES; SKOV, 1989; BERRY; OLSON, 1998; GONÇALVES; ARRUDA, 2013; BERNAL et al., 2017). Additionally, many rheophytic plants are endemic to small areas, even to a single river, and are useful indicators of river health (VAN STEENIS, 1981; 1987). Thus, they are the first species to become locally extinct when a river is dammed (LEES et al., 2016).

Aloysia dusenii is so far recorded only along rivers of South Brazil, which are highly threatened by hydroelectric projects (BRACK et al., 2015). River dams for hydroelectric power transform the lotic environment of the rivers into lentic habitats compromising the conditions for rheophytic species (Fig. 2B). Thus, we emphasize the importance of including this species in the regional lists of threatened flora. Currently, the species is only included in the list of the Santa Catarina threatened flora as Vulnerable (CONSEMA, 2014), where it is disregarded in the Paraná and Rio Grande do Sul lists.

\section{Acknowledgements}

This work was partially funded by Fundação Grupo Boticário de Proteção à Natureza. The authors also thank the Instiuto de Biociências (UFRGS) for providing field work transport, and the two anonymous reviewers for their valuable suggestions. MK thanks CNPq for awarding him a scholarship. Dr. A. Leyva (USA) helped with English editing of the manuscript.

\section{References}

BACHMAN, S.; MOAT, J. GeoCAT - an open source tool for rapid Red List assessments. Botanic Gardens Conservation International, Richmond, v. 9, n. 1, 2012.

BACHMAN, S.; MOAT, J.; HILL, A.; DE LA TORRE, J.; SCOTT, B. Supporting Red List threat assessments with GeoCAT: Geospatial Conservation Assessment Tools. ZooKeys, Washington, v. 150, p. 117-126, 2011.

BENTHAM, G.; HOOKER, J. D. Verbenaceae. In: BENTHAM, G.; HOOKER, J. D. (Ed.). Genera plantarum ad exemplaria imprimis in herbariis Kewensibus servata. Vol. 2, Pt. 2. London: Reeveand Company, 1876. p. 1131-1160.

BERNAL, R.; HOYOS-GOMEZ, S. E.; BORCHSENIUS, F. A new, critically endangered species of Aiphanes (Arecaceae) from Colombia. Phytotaxa, Auckland, v. 298, n. 1, p. 65-70, 2017.

BERNARDES, M. G. Reófitas no vale do rio Pelotas, Sul do Brasil. 2012. 25 f. Trabalho de Conclusão de Curso (Bacharelado em Ciências Biológicas) - Universidade Federal do Rio Grande do Sul, Porto Alegre. 2012.

BERRY, P. E.; OLSON, M. A new rheophytic species of Euceraea (Flacourtiaceae) from Sierra de la Neblina, Venezuela. Brittonia, New York, v. 50, p. 493-496, 1998.

BFG - THE BRAZIL FLORA GROUP. Growing knowledge: an overview of seed plant diversity in Brazil. Rodriguésia, Rio de Janeiro, v. 66, n. 4, 2015.

BRACK, P.; RUPPENTHAL, E. L.; BRACK, I. V. Projetos de hidrelétricas no rio Uruguai: perdas e desafios socioambientais. In: MAGRO, M. L. P. D.; RENK, A.; FRANCO, G. M. S. (Ed.) Impactos socioambientais da implantação da hidrelétrica Foz do Chapecó. Chapecó: Argos, 2015. p. 17-42.

CONSEMA - CONSELHO ESTADUAL DE MEIO AMBIENTE DE SANTA CATARINA. Reconhece a Lista Oficial das Espécies da Flora Ameaçada de Extinção no Estado de Santa Catarina e dá outras providências. Resolução $\mathrm{n}^{-} 51$, de 5 de dezembro de 2014.

CRESPAM, P. C. Estudos na família Verbenaceae no Rio Grande do Sul, Brasil. 2010. 115 f. Dissertação (Mestrado em Botânica) Universidade Federal do Rio Grande do Sul, Porto Alegre. 2010.

FONTANA, J. L. La vegetación reófila del Nordeste Argentino Las comunidades vegetales con Mourera áspera y con Apinagia uguazuensis. Comunicaciones Científicas y Tecnológicas: 
Universidad Nacional del Nordeste, Chaco, 2001. Disponível em: $\quad<$ http://www.unne.edu.ar/unnevieja/Web/cyt/cyt/2001/6Biologicas/B-033.pdf>. Acesso em 12 dez. 2017.

GALEANO-GARCES, G.; SKOV, F. Geonoma linearis - a rheophytic palm from Colombia and Ecuador. Principes, Miami, v. 33, p. 108-112, 1989.

GONÇALVES, E. G.; ARRUDA, A. J. Philodendron carajasense sp. nov. (Araceae), a rheophyte from Carajas Mountain Range, northern Brazil. Nordic Journal of Botany, Lund, v. 32, p. 536539, 2013.

HOYOS-GÓMEZ, S. E.; BERNAL, R. Rheophytes of the Samaná Norte River, Colombia: A hydroelectric project threatens an endemic flora. Tropical Conservation Science, New York, v. 11, p. 1-13, 2018.

IUCN - INTERNATIONAL UNION FOR CONSERVATION OF NATURE. IUCN red list categories and criteria. Version 3.1. 2 ed. Gland and Cambridge: IUCN, 2012. 32 p.

KLEIN, R. M. Reófitas no estado de Santa Catarina, Brasil. In: CONGRESSO DA SOCIEDADE BOTÂNICA DO BRASIL, 30, 1979, Campo Grande. Anais... Campo Grande: SBB, 1979. p. 159169.

KÖHLER, M.; BERNARDES, M. G.; BRACK, P. Espécies Reófitas. In: ROLIM, G. R. (Ed.). Flora da bacia do rio Pelotas: uso e conservação de espécies. Porto Alegre: Universidade Federal do Rio Grande do Sul, 2016. p. 142-154.

LEES, A. C.; PERES, C. A.; FEARNSIDE, P. M.; SCHNEIDER, M.; ZUANON, J. A. S. Hydropower and the future of Amazonian biodiversity. Biodiversity and Conservation, New York, v. 25, p. 451-466, 2016.

LU-IRVING, P.; O'LEARY, N.; O'BRIEN, A.; OLMSTEAD, R. G. Resolving the genera Aloysia and Acantholippia within tribe Lantaneae (Verbenaceae), using chloroplast and nuclear sequence data. Systematic Botany, Laramie, v. 39, n. 2, p. 644-655, 2014.

LU-IRVING, P.; OLMSTEAD, R. G. Investigating the evolution of Lantaneae (Verbenaceae) using multiple loci. Botanical Journal of the Linnean Society, London, v. 171, p. 103-119, 2013.

MARX, H. E.; O'LEARY, N.; YUAN, Y-W.; LU-IRVING, P.; TANK, D. C.; MÚLGURA, M. E.; OLMSTEAD, R. G. A molecular phylogeny and classification of Verbenaceae. American Journal of Botany, St. Louis, v. 97, p. 1647-1663, 2010.
MOLDENKE, H. N. Additional verbenaceous novelties. Phytologia, New York, v. 1, n. 13, p. 440-441, 1940.

MOLDENKE, H. N. A résumé of the Verbenaceae, Avicenniaceae, Stilbaceae, Symphoremaceae, and Eriocaulaceae of the world as to valid taxa, geographic distribution and synonymy. New York: Yonkers, 1959. $495 \mathrm{p}$.

MORRONI, P.; O'LEARY, N. Aloysia. In: Flora do Brasil 2020 em construção. Rio de Janeiro: Jardim Botânico do Rio de Janeiro. Disponível em: <http://floradobrasil.jbrj.gov.br/reflora/ floradobrasil/FB15125>. Acesso em: 12 nov. 2017.

MÚlGURA, M. E.; ROTMAN, A. D.; O’LEARY, N.; PERALTA, P.; ATKINS, S.; FRANÇA, F.; SALIMENA, F. R. G. Verbenaceae. In: ZULOAGA, F. O.; MORRONE, O.; BELGRANO, M. J. (Ed.). Catalogo de las Plantas Vasculares del Cono Sur. Vol. 3. St. Louis: Missouri Botanical Garden, 2008. p. 1-34.

O'LEARY, N.; LU-IRVING, P.; SIEDO, P. M. S. Taxonomic revision of Aloysia (Verbenaceae, Lantaneae) in South America. Annals of the Missouri Botanical Garden, St. Louis, v. 101, n. 3, p. 568-609, 2016.

SALIMENA, F. R. G.; THODE, V.; MULGURA, M.; O'LEARY, N.; FRANÇA, F.; SILVA, T. R. S.; SOUZA, V. C. Verbenaceae. In: FORZZA, R. C. (Org.). Lista de espécies da flora do Brasil. 2010. Rio de Janeiro: Jardim Botânico do Rio de Janeiro. Disponível em: $<$ http://floradobrasil.jbrj.gov.br/jabot/floradobrasil/ FB246>.

SIEDO, S. J. Systematics of Aloysia (Verbenaceae). 2006. $321 \mathrm{f}$. $\mathrm{Ph}$. D. Thesis - The University of Texas, Austin. 2006.

THIERS, B. Index Herbariorum. New York: New York Botanical Garden's Virtual Herbarium, 2017. Available at: <http://sciweb. nybg.org/science2/IndexHerbariorum.asp>.

VAN STEENIS, C. G. G. J. Rheophytes of the world: an account of the flood-resistant flowering plants and ferns and the theory of autonomous evolution. The Netherlands: Sijthoff \& Noordhoff, $1981.424 \mathrm{p}$.

VAN STEENIS, C. G. G. J. Rheophytes of the world: supplement. Allertonia, Kauai, v. 4, 267-330, 1987. 